\title{
SOME POSTCLASSIC QUESTIONS ABOUT THE CLASSIC MAYA
}

\author{
Munro S. Edmonson \\ Tulane University
}

The Postclassic and Colonial texts of the Books of Chilam Balam tell us very little, or so I believe, about the Classic Maya directly. And that little, though very precious, is confined to brief passages in the first three Chronicles, and may have been reshaped to fit the mythological predilections of a later age. The Chronicles being much the best known passages of the Books to Mayanists (Barrera, 1948; Roys 1935), and the events they chronicle being as much as a millennium removed from the composition of the surviving versions, I shall eschew here any attempt to interpret their direct relevance to Mayan Classic history in detail. While the Books do not give us direct answers to our questions about the Classic Maya, they do raise some interesting questions about Classic Maya culture to which archaeology, art history and epigraphy may eventually supply answers. It is the object of this paper to isolate some of these questions, primarily social, calendrical and literary.

The basis of these queries is my recent translations of the Books of Tizimin (Edmonson, n. d. a: completed) and Chumayel (Edmonson, n.d. b: in draft). Largely on internal evidence, I conclude that the extant versions of these two Books date to the period between 1824 and 1837. Even if, as I believe, they contain passages transcribed from pre-Conquest glyphic texts, they are nonetheless separated from the end of the Classic period by nearly a thousand years. They present corresponding problems of interpretation before we use them in the reconstruction of earlier Mayan history.

The historiographic problem may be analogized to the difficulties of using modern ethnography to reconstruct the culture of the preConquest Maya, and the method used here will consciously employ 
this analogy. Just as we must begin our reach back to the fifteenth century by subtracting Spanish culture from that of the modern Maya, so I consider that the attempt to reach back another five hundred years must start with the subtraction from Postclassic Mayan culture of identifiable Postclassic Mexican influences. Some part of the residue just might tell us something about the Mayan tradition before the tenth century. The perils are obvious, but a good question, however arrived at, may sometimes be as valuable as a good answer. My questions concern the kinship system, the calendrical cycles (especially the may and the katun), and literary form.

\section{KINSHIP}

1. Did the Classic Maya have patrilineal descent groups? Although a number of modern Maya groups including the Lacandon (Rees 1977) clearly do, a number of others, including the Yucatecans (Holmes 1977) do not. In a number of instances the evidence points to a shift among the Mayan peoples from patrilineages to the mixed system of bilateral and patrilineal kinship characteristic of the Spanish, or even to straight bilaterality. This cannot be altogether ascribed to Spanish influence, since the Mexica were also bilateral and were an important influence on the Maya during the Postclassic.

I dissent from the view expressed by Haviland (1968) following Murdock (1949) that the evolution of Mayan society proceeded from Hawaiian to Matri-Hawaiian to Patri-Hawaiian to Normal Guinea, as I dissent from Murdock's more general line of argument as being undemostrated. I do agree with most of Haviland's other points, as will be seen.

The evidence of the Books of Chilam Balam points to the inference that the Postclassic Yucatecans, like the modern Lacandon, had a double descent system, at least in the upper classes. But this could have been a consequence of five hundred years or more of bilateral Central Mexican influence interacting with a Mayan patrilineal system. Subtracting this Mexican influence, we would be left with patriliny. An important part of the documentation of such a system relates to the following questions.

2. Did the Classic Maya have preferential cross-cousin marriage? The modern Yucatecans do not, although the Lacandon do. The ethnohistoric evidence suggests that so did the fifteenth century $\mathrm{Yu}-$ catecans, and there is sporadic occurrence of the custom among other Mayan groups, notably in Chiapas (Guiteras Holmes, 1952). The doc- 
umentation of the marriage system is neither direct nor clear in the Tizimin and Chumayel but other dimensions of the kinship system (naming, kinship terminology and politics) appear to point to double descent in the upper class (which is at least partly documented) and not necessarily in the lower class (which is not). Such a system is not directly referrable to the Mexica but could easily be a consequence of trying to maintain status in both patriline and matriline and hence to justify nobility in terms that met at least in part the requirements of bilateral and patrilineal descent at once. Nobles were descendants of known ancestors in both the maternal and paternal lines (al mehenob). The same may have been true of the fifteenth century Quiche (al $q^{\prime}$ aholob). Close in-group marriage for the preservation of status might very well generate such a system within a restricted upper class even apart from foreign influences, and could have done so among the Classic Maya, producing a prescriptive marriage preference for the nobility and a broader latitude of choice among the more numerous peasantry.

3. Did the Classic Mayan kinship terminology then reflect both patrilineage and double descent? That is what is indicated for the Postclassic, both in the Books of Chilam Balam and in the Motul dictionary (Eggan 1938) The question is of course in part lingüistic, and will eventually require both reconstruction and a very difficult kind of epigraphic documentation. But despite the contradictions in the ethnohistorical sources (and they are many), it is difficult to avoid the conclusion that more than one terminological system was in use in the Postclassic, and perhaps in the Classic as well.

4. Did the Classic Maya have virilocal residence, and hence patricompounds? Most modern Mayas are virilocal at least by village, and to a degree by barrio or vecindad, and the latter is also true of the modern Yucatec. Compounds are furthermore rather characteristic of central Mexico, including Tula (Healan 1977), though those of the Mexica were not patrilineally defined. House groups analoguos to the vecindades in modern Yucatan were found at Tikal (Haviland 1970), but have not yet been generally documented for the Classic Maya. Nonetheless the evidence would lead us to expect virilocal residence. The ethnohistoric occurrence of bride price and bride service would lead us to expect uxori-virilocal residence, but that might be very difficult to document archaeologically.

5. Did the Classic Maya have patrilineal primogeniture in succession? Such a tendency is marked among the modern, Colonial and Postclassic Yucatecans as among Colonial Spaniards. It is not a feature 
of central Mexican society, though it is of most Mayan societies. On balance it would be a probable feature of Classic Mayan society even if we had no Classic evidence (see Thompson, n.d.). Such a rule may not have excluded the succesion of women, as in Britain (see Ringle, n.d.).

6. Did the Classic Maya have patrilineal primogeniture in inheritance? Land, houses and household furnishings are the principal forms of property in Middle America, but the sens in which they constitute "property" is subject to considerable variation. "Ownership" of land is often a matter of use-right, sometimes under complex community control, while houses, household furnishings and tools are often individually owned. It is my impression that the Mayan groups tend rather generally towards patrilineal primogeniture with respect to land, houses and agricultural tools and matrilineal primogeniture with respect to household furnishings. Ultimogeniture is an important secondary mode and there are many, many exceptions. Central Mexico has tended more towards bilateral equidistribution. In both areas these tendencies have been overlaid by Spanish testamentary distribution of property (well established among the Quiche by the eighteenth century), and by the complexities introduced by modern land reform laws, particularly the Mexican ejido (Shuman 1974). The Books of Chilam Balam indicate that inheritance was the primary way of acquiring land (an "orphan" is definitionally poor), but say nothing about other forms of property, nor about the inheritance rule. A weak case might be made for expecting patrilineal primogeniture among the Classic Maya.

7. Did the Classic Maya have patronymics? Naming customs may be employed, of course, to signal or emphasize the social groupings implied by the questions already raised, though obviously they don't have to be, and Middle American onomastics is notably complex and variable. The modern Yucatecans have surnames in the Spanish manner. The Postclassic Maya used both in Nahuatl and Maya a matronym followed by a patronym, and both name groups appear to have implied exogamy. Given the questions already raised about patrilineage, double descent and cross-cousin marriage, the Classic Mayan naming system might give us a very useful clue to more fundamental features of the kinship system. Admittedly there could have been lineage or dynastic names not carved on monuments, just as Hanover does not normally appear on statues of Queen Victoria. 


\section{CALENDRICS}

8. Did the Classic Maya have lords of the katun? Postclassic and Colonial Maya clearly did. They received the title Jaguar (Balam), or more rarely Lord Serpent (Ahau Can), both names referring to their robes of office, and were selected on a rotational basis from among the hereditary governors (hal ach uinic) of the thirteen most prominent cities among the 18 provincial capitals. Ostensibly the Classic Maya equivalent could have been lords of cities of the second rank, and their functions would have been different, since by Postclassic times the Jaguar was the supreme ruler of the entire country during his 20 tun term of office.

9. Did the Classic Maya have seats of the katun? The seat of the katun (hetz' katun) was the real capital of the region in Postclassic and Colonial times. Though it only served for 20 tuns at a time, each city competed vigorously for the honor, since it conferred tribute rights and the right to confirm titles to land and public office throughout the region. While these rights must have belonged to ruling lords of major centers, there may nonetheless have been some ritual rotation of subsidiary responsibilities among the cities of the second rank. (See Appendix.)

10. Did Classic Mayan lords have Spokesmen (Chilam) of the katun? Again it is clear that the Postclassic and Colonial Maya did. So too did the Quiche and the Mexica, and the tradition has survived in Quintana Roo into modern times. The Yucatecan Spokesman also acted as the Great Sun Priest (ah noh kin) of the katun and Sun Priest of the Cycle (ah kin may); he was registrar of lands (ah p'iz te) and was responsible for the prophecy of the katun and the examinations of the officials. Obviously such functions must have been discharged by someone in Classic Mayan times, but not necessarily by a "Spokesman". If such a status existed in relationship to the rulership of major centers it should be iconographically visible; if it related to secondary centers it may be harder to document. I am inclined to guess that Spokesmen may be a Postclassic Mexican addition to Mayan culture.

11. Did the Classic Maya give special status to prophets (ah bobat) and hold councils of sages (ah miatz) ? Councils of sages and prophets were held at Mayapan and Chichen Itza; in 13 Ahau (1539) and at Merida in 7 Ahau (1579). Such councils were apparently called in times of crisis to resolve calendrical and religious issues, and one such may well have been responsible for the founding of the League of 
Mayapan in 2 Ahau (1263). They appear to have resembled the Vatican Councils in function, and they commanded enormous respect, representing in Colonial times the highest moral authority in the country. Such a body might for example have had a role in the investiture of the rulers in Classic times as well as later.

12. Did the Classic Maya have nicknames for the katuns? The Postclassic and Colonial Maya did, and related them closely to prophecy, history and religion. From the ethnohistoric texts, the significance of these names is far from clear, and it seems intrinsically unlikely in any case that they would remain unchanged over a period of several centuries, but the names themselves are strongly graphic, suggesting that some similar pattern might be iconographically or epigraphically identifiable: flower, wax, tobacco, deer, bird, black, flint, monkey, turtle. The possible significance of this seemingly minor point is related to the Following question.

13. Did the Classic Maya have systematic katun prophecies? This question is not so simple minded as it sounds. All of nuclear Middle America used the 260 day $t z o l$ kin for prophecy. Most of it also had prophecies based upon the four yearbearers and the 52 year calendar round (kin tun y abil). Only the Yucatecan Maya had katun prophecies. In Colonial times these were sometimes (but rarely) confused with calendar round prophecies, and additional cycles were introduced, notably the seven day week and the 24 year cycle. In the Postclassic there was no such confusion. The suggestion seems strong that the Classic Maya not only had the katun itself but also some significant cyclical prophecies relating to it. The ritual importance of the katuns is fully attested by katun ending monuments. Perhaps some of these contain texts with the curious blend of prophecy and history presented in the Books of Chilam Balam.

14. Did the Classic Maya recognize seats of the cycle (may)? The Books explicitly say they did. In the Postclassic and later the cycle seat $(m a y c u)$ was the primate city of a region. It was not a capital in any normal sense, but rather a holy city, recognized by the title Born of Heaven (ziyan can, can sih), and notable for its sacred ceiba tree $(y a x c h e)$, its sacred grove (tzucub te), its sacred well (ch'en), and its plaza, which was the crossroads (hol can be) and navel of the world. In the Postclassic the seat of the cycle for the Itza, the "Well of the Cycle" or Mayapan from 1243 to 1752 , was not event inhabited after 1452, but it continued to serve as a symbol of the religious authority of the may for another three hundred years. Perhaps the major centers of the Classic Maya were also seats of the cycle (See Appendix). 
Like the katun, the may is uniquely Yucatecan in the ethnohistorical record, and it is known to be prominent among the Classic Maya, being usually identified as the "count" (kahlay) or "fold" (uutz') of the katuns. What is at issue here is how the Classic Maya used it. It does not seem to me far fetched to suggest that the apogee of the Classic cities may have corresponded to counts of the may, as the following closely related question suggests. It would not be necessary to posit that all Classic cities operated on the same synchronized cycle. The Potsclassic Xiu and Itza, for example, disagreed on when to begin and end the may.

15. Did the Classic Maya destroy their cities at the end of a cycle? The Potsclassic Maya destroyed the primate city and its road at the end of the may. There are indications that this "destruction" may have been largely ritual and symbolic, and that the "abandonment" of the city was an evacuation by the ruling dynasty rather than total depopulation. But since the dynasties (e.g., the Xiu and the Itza) did not necessarily agree on the ending date of the cycle, there was room for maneuver in politics, ideology and warfare. The Postclassic theory did not end the legitimacy or existence of a dynasty, but only its right to rule a particular city. A somewhat irregular system of rotation appears to have operated, consonant with the generally cycle Mayan world view.

Evidence of defacement of monuments is widespread in the Classic Mayan cities, and it seems possible that archaeological as well as epigraphic, calendrical or iconographic evidence might be adduced on this question. There is furthermore some evidence that the may was not only employed in Classic Tikal and Palenque but that it was defined like the Postclassic Xiu cycle as beginning in 6 Ahau and ending in 8 Ahau. This appears to be the periodicity of the dynasty that begins with Stormy Sky at Tikal and Lord "X" at Palenque, both initiated at the end of 8 Ahau in 9.0.0.0.0. (Thompson, n.d.; Ringle, n.d.). Thompson (1965:353) notes an abrupt change in the style of Tikal near 8 Ahau at 9.13.0.0.0 (See Appendix).

16. Does the Classic Mayan cessation of building and erection of monuments correspond to a revolution in calendrical theory, or to the fulfillment of a cyclical prophecy? Major events of Postclassic and Colonial history can be shown to have a close link to the mystique of the katun and the may, including the founding and fall of Mayapan, the conversion of the Xiu, the Peten Itza and teh northern Itza, and even the Caste War (Bricker, n.d.; Edmonson 1976; Shuman, n.d.). Again, it would not be necessary for the so-called Mayan collapse 
to have occurred simultaneously in different places, for they may have been operating on different cycles even within a common calendar.

There would also appear to be a relationship between the major known changes in the Calendar (Edmonson 1976) and important political events. The partial shift from the Tikal to the Campeche calendar in the Usumacinta valley and vicinity may have corresponded to the inauguration of the Potsclassic. The shift to the Mayapan calendar in Yucatan in 1539 is startlingly congruent with the Spanish Conquest in that area. The shift to the Valladolid calendar in 1752 marks the final separation of the eastern Maya from their more acculturated western neighbors, and sets the stage for the Caste War. It is not necessary to exclude other causes to suppose that the ending of the Mayan Classic may have been conditioned by cyclic prophecy: the Mayan prophets were often subtle, percipient and realistic. But their prophecies have a way of being self-fulfilling as well, and the last known long-count date, from San Lorenzo, falls in 8 Ahau at 10.6.0.0.0, as does the earliest long-count date generally accepted as Mayan, that of the Tuxtla Statuette, in 8 Ahau at 8.7.0.0.0. Indeed, the pattern of Mayan history is strongly suggestive of a continuous tradition of major cultural and political changes at the recurrences of the folding of the may every time 8 Ahau comes around. See Table I and Appendix.

TABLE I

THE REGURRENCES OF 8 AHAU

\begin{tabular}{|c|c|c|}
\hline $\begin{array}{r}846 \\
590 \\
334 \\
77\end{array}$ & $\begin{array}{l}\text { 5.15.0.0.0 } \\
\text { 6. } 8 \cdot 0.0 .0 \\
\text { 7. } 1.0 .0 .0 \\
7.14 .0 .0 .0\end{array}$ & $\begin{array}{l}\text { ?Olmec Period, Early Formative } \\
\text { ?Middle Formative } \\
\text { ?Late Formative } \\
\text { ?Tres Zapotes seats the cycle }\end{array}$ \\
\hline $\begin{array}{l}179 \\
435 \\
692\end{array}$ & $\begin{array}{l}\text { 8. } 7 \cdot 0.0 .0 \\
\text { 9. } 0.0 .0 .0 \\
9.13 \cdot 0.0 .0\end{array}$ & $\begin{array}{l}\text { ?Tuxtla and Tikal seat the cycle } \\
\text { Tikal and Palenque seat the cycle } \\
\text { Tikal, Palenque, Chichen Itza and } \\
\text { Bacalar seat the cycle }\end{array}$ \\
\hline 948 & 10. 6.0 .0 .0 & $\begin{array}{l}\text { Champoton and Chichen Itza seat } \\
\text { the cycle; end of long-count } \\
\text { monuments }\end{array}$ \\
\hline 1204 & 10.19.0.0. & $\begin{array}{l}\text { ?Mayapan seats the cycle } \\
\text { Fall of Mayapan: ?Tayasal se }\end{array}$ \\
\hline 146 & 11.12 .0 & $\begin{array}{l}\text { Fall of Mayapan; ?Tayasal seats } \\
\text { the cycle }\end{array}$ \\
\hline 1697 & 12. 5.0 .0 .0 & $\begin{array}{l}\text { Conquest of the Peten Itza; ?Va- } \\
\text { lladolid seats the cycle }\end{array}$ \\
\hline
\end{tabular}




\section{LITERATURE}

17. Did the Classic Maya use parallelistic couplets? It now seems well established that they did. In a previous paper (Edmonson, 1965) I suggested that the form might be related to the common occurrence of paired glyph blocks, but this no longer looks likely as a rule, event though it does occur. Despite criticisms and refinements of my argument (Edmonson, 1971) that all formal Mayan discourse is in parallelistic couplets, I remain persuaded that the exceptions to this rule are rare enought that it has positive utility in working out the syntactic and orthographic problems of Colonial texts, and I suspect that the same may ultimately prove true of the Classic inscriptions as well. The form is almost the definition of native "poetry" from the Rio Grande to Tierra del Fuego.

18. Did the Classic Maya use couplet kennings? Couplet kennings or difrasismos are ubiquitous in Nahuatl poetry and in the supposedly prose texts of the Yucatecan Books as well. They are markedly rare in the Popol Vuh, though they do occur. The device depends on the dialectic process of combining the elements of a dichotomy or other dyad to produce a third and esoteric meaning (e.g., rope and cord means war). I am inclined to think this particular form may have been introduced into Yucatan from central Mexico and hence may not occur among the Classic Maya, but the evidence is insufficient for a strong supposition. The presence of such a device in Classic period inscriptions could obviously materially affect their intelligibility, and particularly so in the context of the following question.

19. Did the Classic Maya share esoteric metaphors with their cultural descendants in Postclassic Yucatan? This is a complex problem, and particularly so in view of the historic time and lingüistic distance between them. The most explicit data on Colonial metaphors of this type, which differ from the kennings in that they are not necessarily paired, are contained in the ritual riddles of the lords. Some of these riddles involve obvious Christian elements. They are also explicitly identified with Tula, being designated as "The Language of Zuyua". Nonetheless, the metaphoric usages of the Yucatecan Books generally attain the opacity of intentional obscurantism, and some of these might very well be present in Classic inscriptions.

The Colonial texts produce the impression that their obscurity may have been partially designed to keep Mayan traditions from the Spanish. They were not at all intended to be secret from the Mayan peasantry, who are frequently apostrophized directly. And there are even now in Quintana Roo Mayas who can read and understand them. It seems to me quite possible therefore that the glyphic texts of the 
Classic period could have contained a substantial esoteric and metaphoric element without necessarily impeding their intelligibility for the commoners and laymen to whom they must have been in part addressed. A certain deviousness and indirection may well be part of Mayan tradition. Flies are ancestors; the moon is the end; the sun is the beginning; stalks are lineages; monkeys are peasants.

20. Finally, did the Classic Maya conceive of and use writing itself the way the Postclassic Maya did? Did they write in steps ( $\left.t z^{\prime} a c a b\right)$ of glyphs? Did they write letters? Did they write their katun prophecies? Did they have public readings? Did they write prophecy (bobatil) in books (huunob) and memorials (natabal) on stone (tun)? Were the prophetic books kept locally? And on the other hand, were ritual, drama, prayer and song entirely confined to oral tradition? For the Postclassic Maya, the answers to all of these questions is "yes".

The Postclassic codices certainly suggest that the Classic Maya had books of divination and astronomy, and it would be surprising if they had not had books of historical prophecy comparable to the Books of Chilam Balam as well. But the content of such works need not have been carved in stone, and perhaps it was not. It may well be that most of the genres of Classic Mayan literature are forever lost to us.

\section{CONCLUSION}

It is hard to imagine attempting to reconstruct the England of Beowulf from a collection of brief and esoteric prophecies composed by various hands from Chaucer's to Coleridge's and preserved only in a nineteenth century copy. Would we be trying to project backwards the later character of the English monarchy? The ideology of Christianity? The style of Medieval and Renaissance literature? Perhaps not. But if we concentrated on kinship, the calendar and really ubiquitous features of English poetry and writing we might not be too wide of the mark. Even so, we should be left feeling more than a little tentative about the attempt.

Only a sense of real pressure on the part of my Classicist colleagues induces me to speculate on possible points of similarity between the eighth century Mayas and their descendants of five hundred to a thousand years later. I can think of some questions of possible utility, but the answers will clearly have to come from the evidence of the Mayan Classic itself. Once I saw that I could not stop at thirteen such questions, I have aimed at twenty, in the belief that the Classic Maya would have approved. 


\section{APPENDIX}

\section{POSSIBLE CLASSIC SEATINGS OF THE KATUN AND THE $M A Y$}

The following table has been drawn up as a documentation and speculation in relation to the recurrence of the may cycle ending on 8 Ahau katuns and its possible relevance to the chonology of Mayan history. As is summarized in Table I in the text, it is possible to consider eleven such cycles within the framework of Middle American prehistory, from the ninth century B. C. to the twentieth century A. D. The eleventh such cycle would be completed in 2016 A.D., according to the most recent Mayan calendar reform, that of Valladolid.

It is of some interest that the first three of these cycles come within three katuns of accepted dates for the beginnings of the Olmec period, the Middle Formative and the Late Formative respectively, and that the earliest long-count dates of the next two cycles fall outside of Mayan country as usually defined (Tres Zapotes, El Baul and Tuxtla).

By the end of the fifth cycle however (9.0.0.0.0), we have enough dated monuments from the Peten that it does not seem impossible to speculate on the seating of the may at Tikal (or by a dynasty that eventually came to Tikal) at the outset of that cycle.

By the sixth cycle (ending 9.13.0.0.0) we are on somewhat solider ground in supposing on the basis of dynastic genealogy that Palenque and Tikal were cycle seats, and on somewhat looser dating that Coba, Copan and Altar de Sacrificios could have been.

In the seventh cycle (ending 10.6.0.0.0) Palenque and Tikal probably started the cycle at least as seats of the may. Chichen Itza and Bacalar are explicitly identified as such in the Books of Chilam Balam, and Dzibilchaltun and Seibal appear to me to be likely. The last monumental long-count inscription ends this cycle.

Champoton and Chichen Itza are identified in the Books as the seats of the eighth cycle (ending 10.19.0.0.0), and it seems possible that Uxmal could have been a contender as well. The end of the cycle corresponds to the end of the Modified Florescent period.

Uxmal and Mayapan are given in the Books as the major cities of the ninth cycle (ending 11.12.0.0.0), though only Mayapan is identified as the cycle seat. The Chronicles date the founding of Uxmal and Mayapan to 11.2.0.0.0. rather than the expected date of 10.19 .0 .0 .0 . In any case this was the Decadent period, and the time of the League of Mayapan, which fell and was destroyed at the end of the cycle. 
Despite its destruction and abandonment, Mayapan continued to be considered the seat of the tenth cycle, which should have ended in 12.5.0.0.0. Although the Books do not name it as a cycle seat, Tayasal almost certainly served in that capacity throughout the tenth cycle, and at the end of the cycle it was conquered at its own request. It seems possible to me that Tixchel could have served as cycle seat in the west, and Merida actually did to in the northwest, though it did not seat the cycle until the fifth katun and then only lasted for six katuns (11.16.0.0.0 to 12.2.0.0.0). Calendrical reasons relating to the Mayapan calendar reform of 1539 were involved (Edmonson, 1976).

Zaci (Valladolid) was established as the sole seat of the eleventh cycle in 12.7.0.0.0, rather than in 12.5.0.0.0, as was to be expected. The reasons appear to have been calendrical, and have been detailed elsewhere (Edmonson, 1976;n .d. a). In any case this coincided with the abandonment of the traditional katun of 20 tuns in favor of a new katun of 24 years (haab), and hence the final destruction of the longcount dating system (which had been in disuse since 10.6.0.0.0 anyway). Valladolid seated its last katun at Coba in 1800 A.D.

It seems clear that the mystique of the may must have dominated a substantial period of Mayan history. In order to scan the data for possible katun seats, I have entered in the Table the known seats of the katuns from the Books of Chilam Balam, from Otzmal (seated in 1401 ) to Coba (seated in 1800). I have then added the monumentally dated archaeological sites, from Tres Zapotes (which could have been seated in 38 B.C.) to San Lorenzo (which could have been seated in 928 A.D.) I have also included a few northern sites that are not monumentally dated (Balankanche, Ikil, Uxmal, Xcaret), and two early radiocarbon dated sites (Kaminaljuyu and La Venta). All of these additional sites appear in parentheses. The archaeological sites are listed in the Table by their earliest known dates. They could possibly have served as seats of the katun any time thereafter. The span of dates from particular sites will be found in the following Index together with source citations.

Somewhat arbitrarily I have divided the Mayan area into six geographic regions which appear to corresponde at least roughly to the number and location of the cities important enough to have served as seats of the cycle. Finer subdivisions could be made and perhaps should be, particularly in the Puuc, Chenes, Rio Bec, Usumacinta and Western areas. No real conclusions can be drawn from the site listings except perhaps to note that there appear to be about enough dated secondary sites in each area to suggest the possibility of a rotational system of katun seats from at least the fifth century A.D. on. 
હัँ

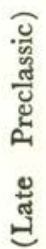

ॐ

a o

벙 司

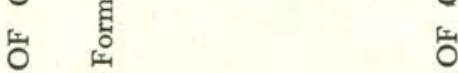

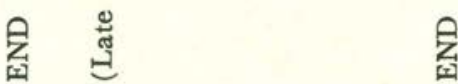

ปั

这

芯 灾

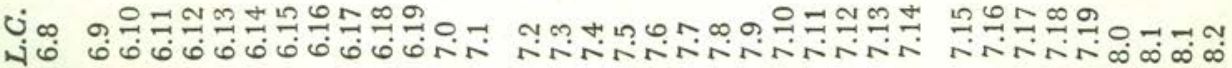
छี๊

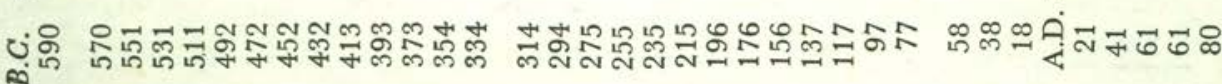
Estudios de Cultura Maya. V́l. XII, 1979 Instituto de Investigaciones Filológicas/ Centro de Estudios Mayas, UNAM http://www.iifilologicas.unam.mx/estculmaya/ 

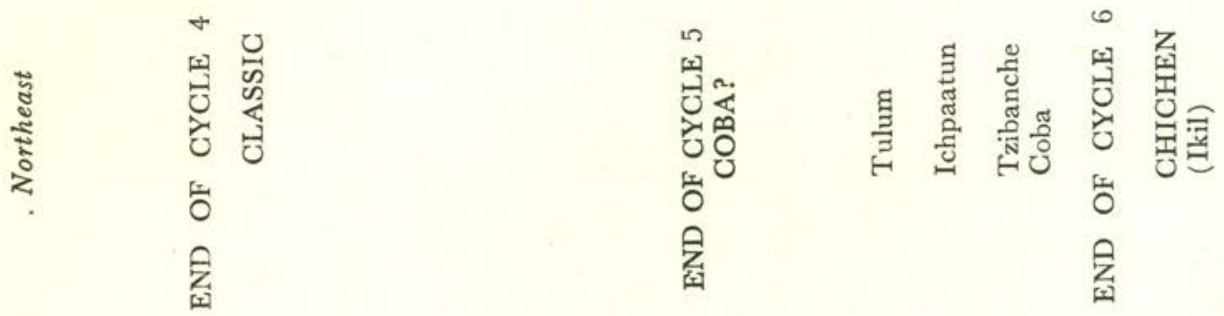

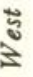<smiles>C1CC1C1CC1</smiles>

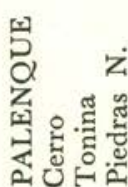

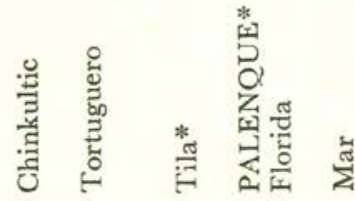

نำแนn

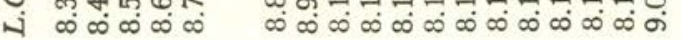

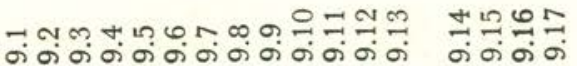
ฐี้ $m-\simeq 0$ ம+กต $0+\alpha m=0 \pi n-\simeq 0 \infty$ $\omega+\mathrm{Nm}$

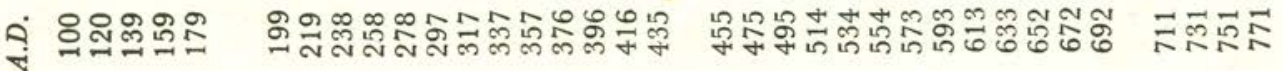



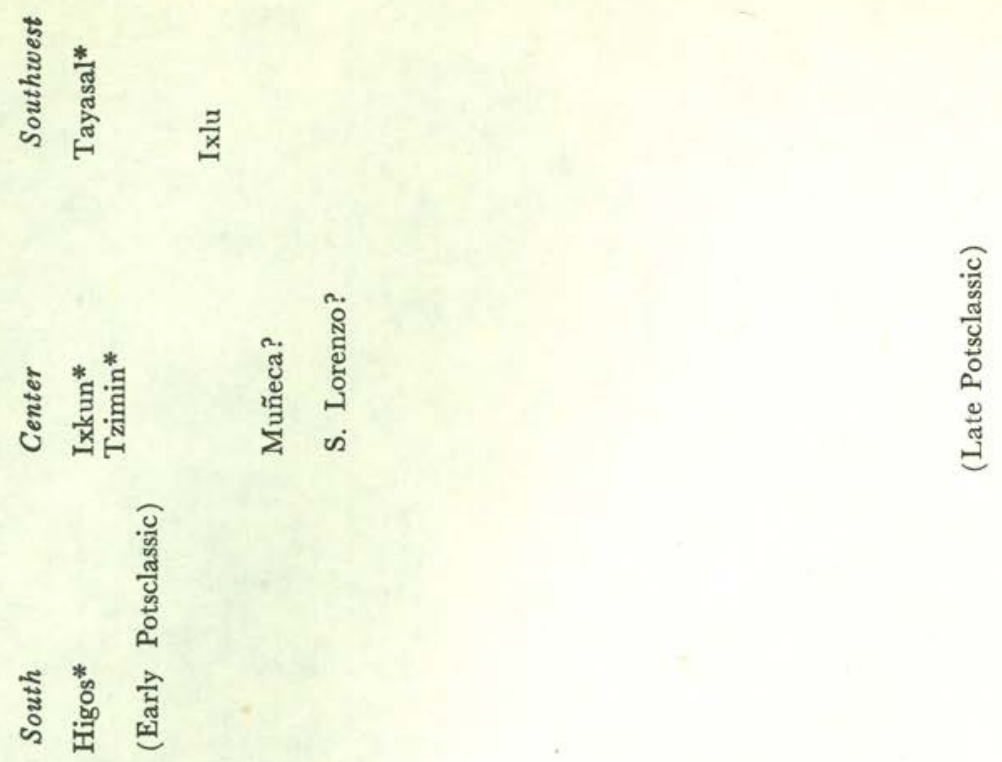

0
0
0
0
0
0
0
0
0
0
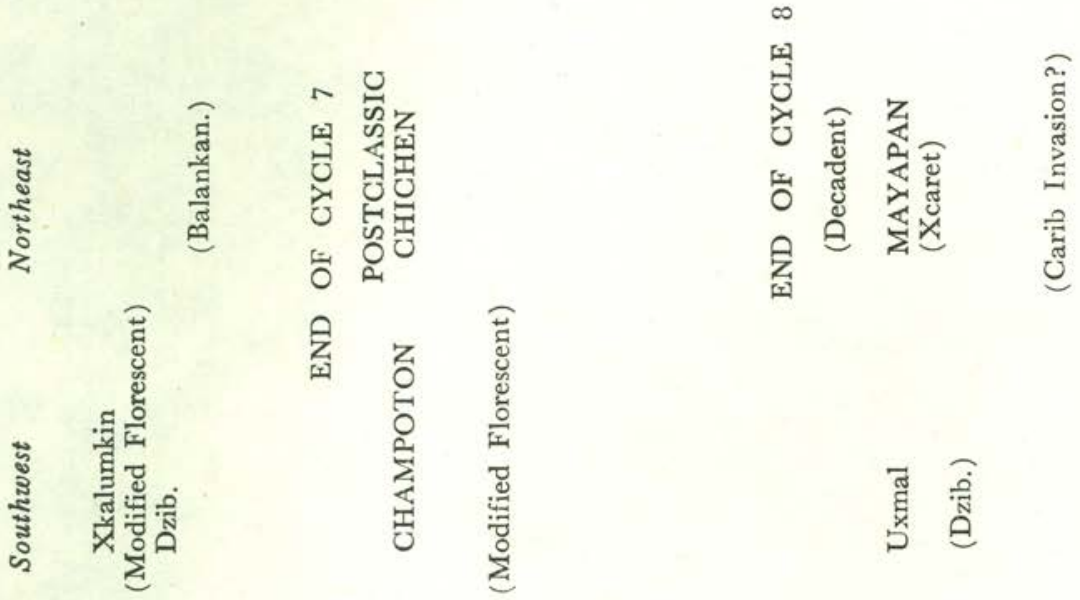

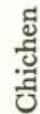
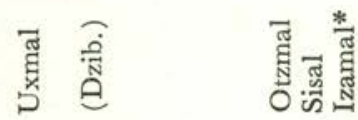

इু

ن

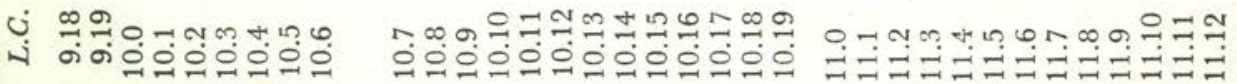

ป⿱艹

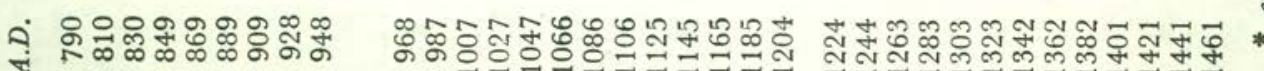

Estudios de Cultura Maya. Vol. XII, 1979

Instituto de Investigaciones Filológicas/

Centro de Estudios Mayas, UNAM

http://www.iifilologicas.unam.mx/estculmaya/ 


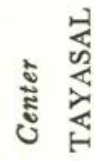

ڤัँ

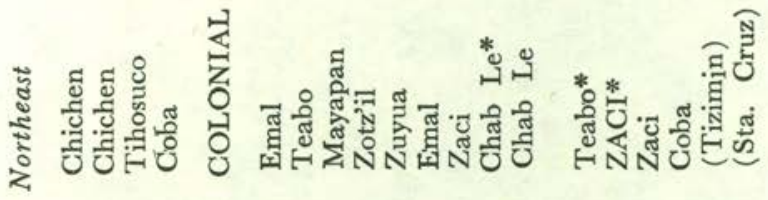

으

뙨
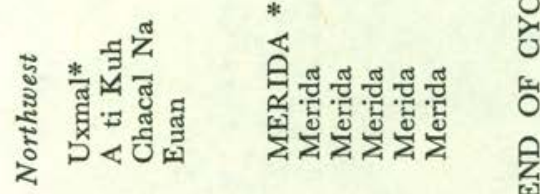

ํํำ

是

范苾

نํㅓ

ปิ่

ปี

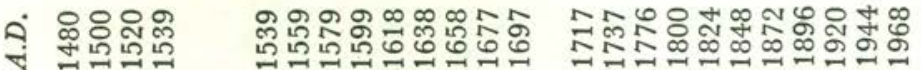

Estudios de Cultura Maya. Vol. XII, 1979

Instituto de Investigaciones Filológicas/

Centro de Estudios Mayas, UNAM

http://www.iifilologicas.unam.mx/estculmaya/ 


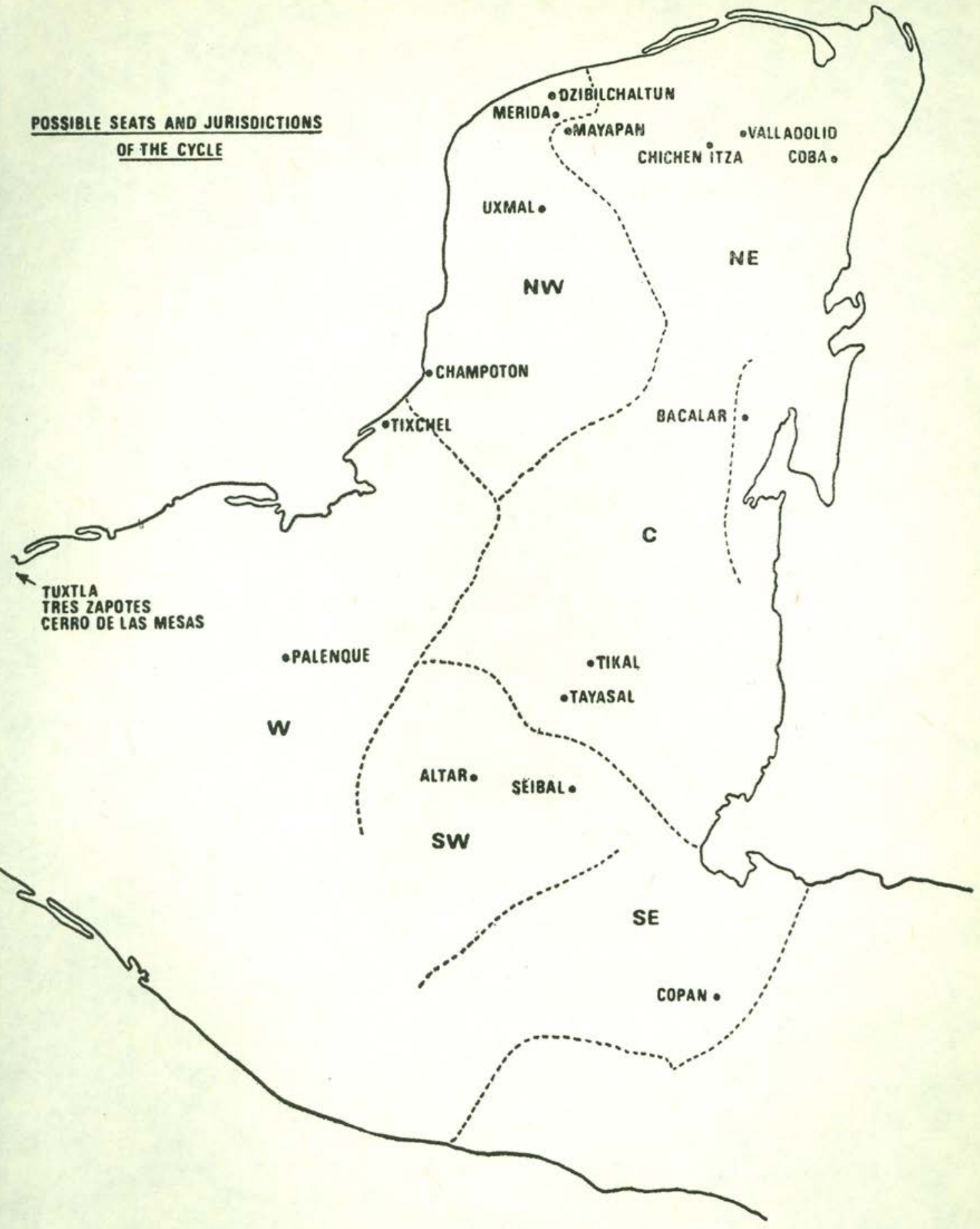




\section{INDEX}

Except as noted, the data below are drawn from Morley (1946: $65 \mathrm{ff})$. Cities listed in capitals are possible seats of the cycle. The others are possible seats o fthe katun. Each archaeological site is listed by its earliest date; latest dates will be found in the alphabetical Index that follows. Data for the Postclassic and Colonial periods are from the Books of Chilam Balam except as noted Archaeological chronology for the Yucatan area is drawn from Andrews V (1975), and for the Southern Lowlands from Willey et al. (1964).

Aguas calientes 9.18 (sea Tayasal, Poco Uinic)

Altar de Sacrificios 9.2-10.1 (Graham 1973)

La Amelia 9.17-9.19

BACALAR 9.13-10.6 (Chilam Balam; se Quirigua)

Balakbal 8.19 (see Uolactun)

Balankanche 10.2 (Andrews IV 1970)

El Baul 8.0 (Coe 1957)

Bonampak 9.8-9.18 (Graham 1973)

Calakmul 9.10-9.19

Cancuen 9.18-9.19 (see Los Higos)

El Caribe 9.18 (see Ixkun)

El Cayo 9.14-9.19 (Graham 1973; see also the site of Morales)

Cerro de las Mesas 9.2-9.5

Chab Le 12.4-12.5 seat of katun (Chilam Balam; see Zaci)

CHAMPOTON 10.6-10.12; seat of cycle 10.6; seat of katun 11.12 (Chilam Balam)

CHICHEN ITZA 9.13-10.19; 11.12-11.14 (Chilam Balam)

Chinkultic 9.8-9.19 (Borhegyi 1968; Morley 1946)

Coba 9.10-9.19

Comitan 10.3 (see Quen Santo)

COPAN 9.2-9.19

DZIBILCHALTUN 10.1 (Andews IV \& Andews V, 1978)

El Encanto 9.9 (see Uxul)

La Esperanza 9.8

Etzna 9.12-9.18

La Florida 9.15-9.17

Los Higos 9.18 (see Cancuen)

Holactun 9.16 (see Xtampak)

La Honradez 9.15-9.19 (see Xamantun)

Hunac Thi 11.13 seat of the katun (Chilam Balam)

Ichpaatun 9.8

Ikil 9.15? (Andrews IV, 1968)

Itzimte 9.15 (see Xamantun)

Ixkun 9.18-9.19 (see El Caribe)

Ixlu 10.2-10.3

Izamal 11.2 (Chilam Balam; see Kan Caba) 
Jaina 9.11

KAMINALJUYU 1546 B.C. - 400 A.D. radiocarbon (Willey et al. 1964)

Kan Caba 11.12 (Chilam Balam; see Izamal)

Leyden Plaque 8.15

La Mar 9.17-9.18

MERIDA 11.16 seat of cycle; 11.16-12.2 sea of katun (Chilam Balam)

Morales 9.14-9.17 (see El Cayo, Palenque)

Muñeca 10.4 (Thompson 1965)

Naachtun 9.5-9.18

Nakum 9.17-10.1

Naranjo 9.9-10.0

Oxkintok 9.2

Oxpemul 9.15-10.0 (see Xamantun)

PALENQUE 9.0-9.18 (Morley 1946:65ff; Ringle, n.d.; see Morales, El Cayo, Quexil, Tila)

El Palmar 9.14-10.0

Piedras Negras 9.4-9.19

Poco Uinic, Santa Elena 9.18 (see Tayasal, Aguas Calientes)

Polol 9.16-9.18

Pomona 9.13-9.18 (see Seibal)

Pusilha 9.7-9.15

Quen Santo 10.3 (see Comitan)

Quexil 9.13 (see Tila)

Quirigua 9.14-9.19

San Lorenzo 10.6 (Thompson 1965)

Seibal 9.16-10.4 (see Pomona, Tzendales)

Tayasal 9.18-10.2 (see Aguas Calientes, Poco Uinic)

Teabo 12.6-12.7 sea of katun (Chilam Balam; s see Zaci)

TIKAL 9.0-10.2 (Morley 1946:65ff; Thompson, n.d.; see Palmar)

Tila 9.13-10.0 (see Quexil)

Tonina 9.3-9.19

Tortuguero 9.10-9.14 (Morley 1946:65ff; Graham 1973)

TRES ZAPOTES 7.16 (Coe 1957)

Tulum 9.7

Tuxtla Statuette 8.7

Tzendales 9.13 (see Seibal)

Tzibanche 9.10-10.4

Tzimin Kax 9.19-10.1

Uaxactun 8.15-10.3

Uolantun 8.19 (see Balakbal)

UXMAL 11.2; seat of katun 11.13 (Chilam Balam); 570 A. D. radiocarbon (Willey et. al. 1964; see Hunac Thi)

Uxul 9.9-9.18 (see El Encanto)

Valladolid (see Zaci)

La Venta 1160 B.C. - 280 B.C. radiocarbon (Willey et. al. 1964). Xamantun 9.15-9.19 (see La Honradez, Itzimte, Oxpemul)

Xkalumkin 9.19 
Xtampak, Santa Rosa 9.16-10.2 (see Holactun)

Xultun 9.4-10.3

Yaxchilan 9.4-9.18 (Morley 1946:65ff; Graham 1973)

ZACI 12.3, 12.8 seat of katun; 12.7 seat of katun (Chilam Balam; see Teabo)

El Zapote 9.0 (Graham 1973)

\section{BIBLIOGRAPHY}

ANDREWS, E. WyLlys IV

1965 "Archaeology and Prehistory in the Northern Maya Lowlands: an Introduction". In R. Wauchope (ed). Handbook of Middle American Indians, 2:288-330. University of Texas Press. Austin.

1968 "The Ruins of Ikil. Yucatan, Mexico". Middle American Research Institute Publication. 31:69-80. Tulane University, New Orleans.

1970 "Balankanche, Throne of the Tiger Priest". Middle American Research Institute Publication 32. Tulane University, New Orleans.

Andrews, E. Wyllys iv and $E$. Wyllys Andrews v

1978 "Excavations at Dzibilchaltun, Yucatan, Mexico". Middle American Research Institute Publication 48. Tulane University, New Orleans.

ANDREWS, E. WyLLYS v

1975 "Archaeological Context and Significance of the Polychrome Pottery". Middle American Research Institute Publication 31: 234-247. Tulane University, New Orleans.

ANDRews, E. WyLlys v ANd Anthony ANDREWS

1975 "A Preliminary Study of the Ruins of Xcaret, Quintana Roo, Mexico". Middle American Research Institute Publication 40. Tulane University, New Orleans.

Barrera Vásquez, Alfredo

1948 El Libro de los libros de Chilam Balam. Fondo de Cultura Económica, México.

Borhegyi, Stephan F. DE

1968 "Archaeological Reconnaissance of Chinkultic, Chiapas, México". Middle American Research Institute Publication 26:119. 133. Tulane University, New Orleans.

BRecker, Victoria R.

n.d. The Indian Christ, the Indian King. University of Texas Press,

Coe, Michael D. Austin. (In press.)

1957 "Cycle 7 Monuments in Middle America: a Reconsideration". American Anthropologist 59:597-611. Menasha.

Edmonson, Munro S.

1965 "Literary Style in the Dresden Codex". Paper read at the annual meeting of the American anthropological Associations, Denver.

1971 "The Book of Counsel: the Popol Vuh of the Quiche Maya of Guatemala". Middle American Research Institute Publication 35. Tulane University, New Orleans. 
1976 "The Mayan Calendar Reform of 11.16.0.0.0". Current Anthropology 17:713-717. The Hague.

n.d. a The Ancient Future of the Maya: The Book of Chilam Balam of Tizimin. MS submitted for publication.

n.d. b Heaven Born Merida and Its Destiny: the Book of Chilam Balam of Chumayel. In draft.

EGGAN, Fred

1938 "The Mayan Kinship System and Cross-Cousin Marriage". American Anthropologist 36:188-202. Menasha.

Graham, John A.

1973 "Aspects of Non-Classic Presences in the Inscriptions and Sculptural Art of Seibal". In T. Patrick Culbert (ed.) The Classic Maya Collapse 207-219. University of New Mexico Press, Albuquerque.

Guiteras Holmes, Calixta

1952 "Social Organization". In Sol Tax (ed.) Heritage of Conquest 97-118. Free Press, Glencoe.

Haviland, William A.

1968 "Ancient Lowland Maya Social Organization". Middle American Research Institute Publication 26. Tulane University, New Orleans.

1970 "Tikal, Guatemala and Mesoamerican Urbanism". World Archaeology 2:186-198. London.

Healan, Dan M.

1977 "Architectural Implications of Daily Life in Ancient Tollán, Hidalgo, Mexico". World Archaeology 9:140-156. London.

Holmes, Bárbara

1977

Morley, Sylvanus G.

1946 The Ancient Maya. Stanford University Press, Stanford.

Murdock, George Peter

1949 Social Structure. Macmillan, New York.

Rees, Mighael J.

1977 Mathematical Models of Lacandon Kinship. Unpublished doctoral disseration, Tulane University, New Orleans.

Ringle, WrLliam M.

n.d. The Historical Inscriptions at Palenque. MS in possession of the author, Tulane University, New Orleans.

Roys, RaLPH L.

1935 The Book of Chilam Balam of Chumayel. University of Oklahoma Press, Norman.

Shuman, Malcolm K.

1974 The Town Where Luck Fell. Unpublished Doctoral Dissertation, Department of Anthropology, Tulane University, New Orleans.

n.d. Problems and Pitfalls in Lowland Mayan Ethonohistory. MS in possession of the author, Tulane University, New Orleans.

Thompson, J. ERic S.

1965 "Archaeological Synthesis of the Southern Mayan Lowlands; an Introduction". In R. Wauchope (ed.) Handbook of Middel American Indians 2:331-359. University of Texas Press, Austin.

Thompson, Philip C.

n.d. Dynastic Marriage and Succession at Tikal. MS in possession of the author, Tulane University, New Orleans. 
Willey, Gordon R., Gordon F. Ekholm and René F. Millon

1964 "The Patterns of Farming Life and Civilization". In R. Wauchope (ed.) Handbook of Middle American Indians 1:446-498. University of Texas Press, Austin. 